\title{
Cholestatic Jaundice as a Paraneoplastic Manifestation of Prostate Cancer Aggravated by Steroid Therapy
}

\author{
Min Kyu Kang Jung Gil Park Heon Ju Lee \\ Division of Gastroenterology and Hepatology, Department of Internal Medicine, College of Medicine, Yeungnam \\ University, Daegu, Republic of Korea
}

\section{Significance of the Study}

- As a paraneoplastic manifestation of advanced prostate cancer, cholestatic jaundice can be exacerbated by the use of steroids and it can be improved by appropriate antiandrogen therapy.

\section{Keywords}

Androgen receptor $\cdot$ Bicalutamide $\cdot$ Jaundice $\cdot$ Prostate cancer · Prednisone

\begin{abstract}
Objective: To report a rare case of paraneoplastic jaundice as a manifestation of prostate cancer. Clinical Presentation and Intervention: We report on a case of paraneoplastic syndrome in a 72-year-old man with prostate cancer that manifested with idiopathic jaundice. Although steroids can be used as treatment in patients with prostate cancer, they could exacerbate paraneoplastic jaundice. The jaundice that flared up after treatment with $40 \mathrm{mg}$ prednisone was improved with antiandrogen treatment. Conclusion: Physicians should be aware of the possibility of paraneoplastic jaundice in patients with prostate cancer. Appropriate antiandrogen therapy should be considered for paraneoplastic jaundice in these patients.

(C) 2018 The Author(s)

Published by S. Karger AG, Basel
\end{abstract}

\section{Introduction}

Paraneoplastic cholestasis in patients with prostate cancer, which has been previously shown to improve with the use of antiandrogen agents, has been rarely reported [1-9]. As maintenance therapy for metastatic prostate cancer, corticosteroids have been widely used for decades [10]. Here, we report a patient with metastatic prostate cancer in whom we observed deterioration of paraneoplastic jaundice after a short course of treatment with 40 mg prednisone. The patient showed improvement after antiandrogen treatment.

\section{Case Report}

A 72-year-old man visited our emergency department due to jaundice and anorexia which had persisted for 2 months. The results of his physical examination were unremarkable. Liver function tests revealed the following values: serum bilirubin level (SBL), $13.1 \mathrm{mg} / \mathrm{dL}$; serum albumin level, $4.45 \mathrm{~g} / \mathrm{dL}$; serum aspartate ami-

\section{KARGER}

E-Mail karger@karger.com www.karger.com/mpp

\section{(C) 2018 The Author(s)}

Published by S. Karger AG, Basel

Karger

Open access

This is an Open Access article licensed under the Creative Commons Attribution-NonCommercial-4.0 International License (CC BY-NC) (http://www.karger.com/Services/OpenAccessLicense), applicable to the online version of the article only. Usage and distribution for commercial purposes requires written permission.
Division of Gastroenterology and Hepatology, Department of Internal Medicine College of Medicine, Yeungnam University

170 Hyeonchungno, Nam-gu, Daegu 42415 (Republic of Korea)

E-Mail gsnrs@ naver.com 


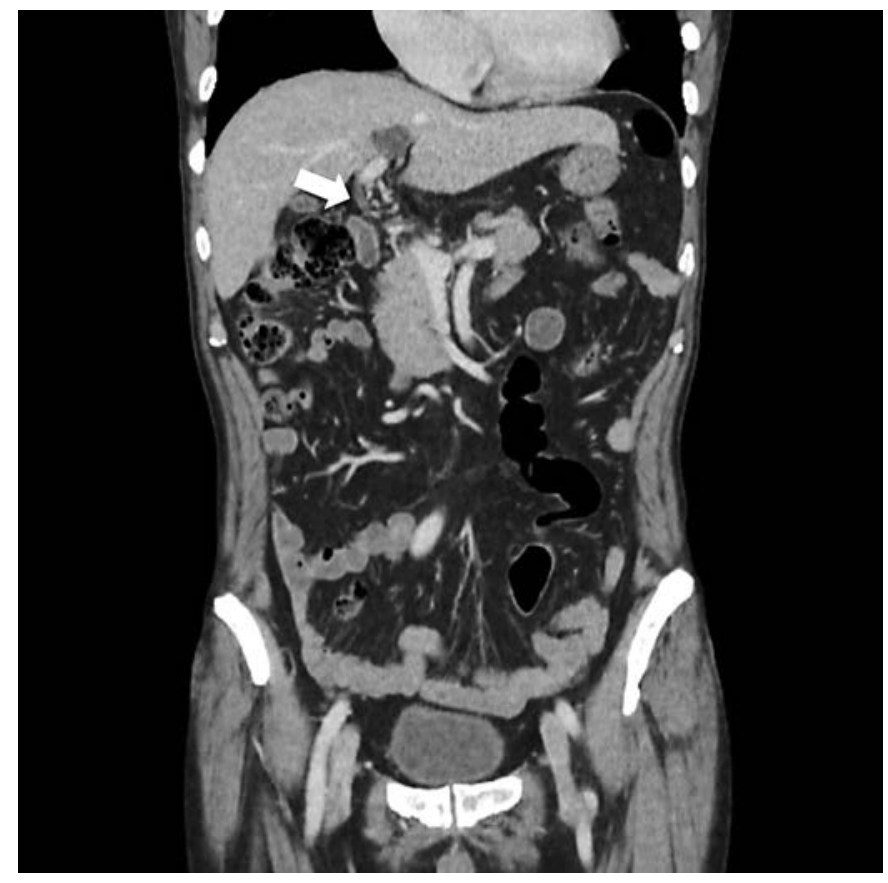

Fig. 1. Abdominal computed tomography scan showing no evidence of biliary obstruction including common bile duct (arrow) and intrahepatic ductal dilatation.

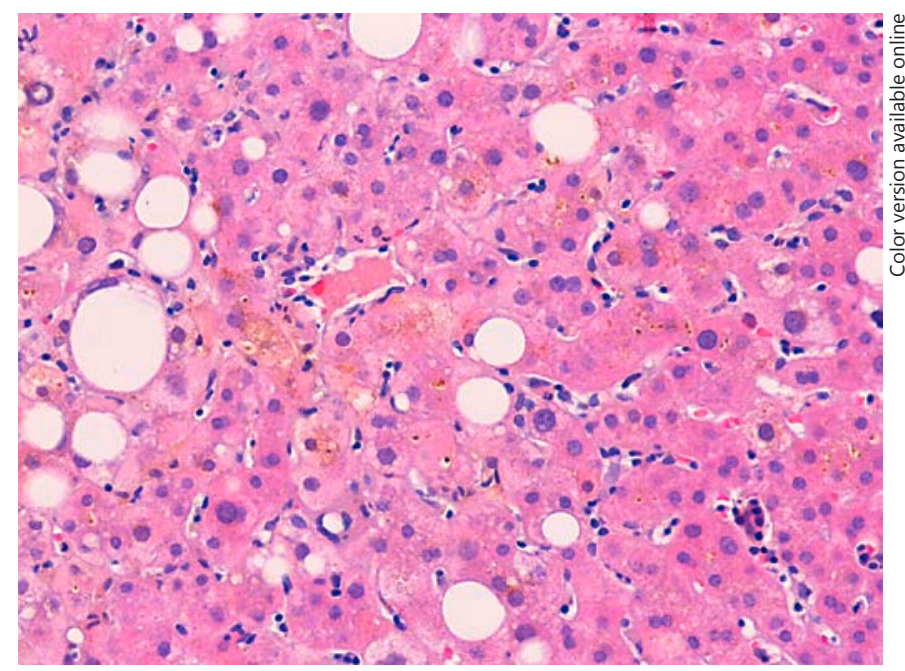

Fig. 3. Microscopic examination result showing mild infiltration of lymphocytes and bile plugs in the portal tract and bile canaliculi. Hematoxylin and eosin stain. $\times 200$.

notransferase level, 112 IU/L; serum alanine aminotransferase level, $146 \mathrm{IU} / \mathrm{L}$; and prothrombin time-international normalized ratio, 1.1. Serum hepatitis B surface antigen and hepatitis $C$ antigen tests were all negative. Abdominal computed tomography revealed enlargement of the prostate gland and no evidence of obstructive

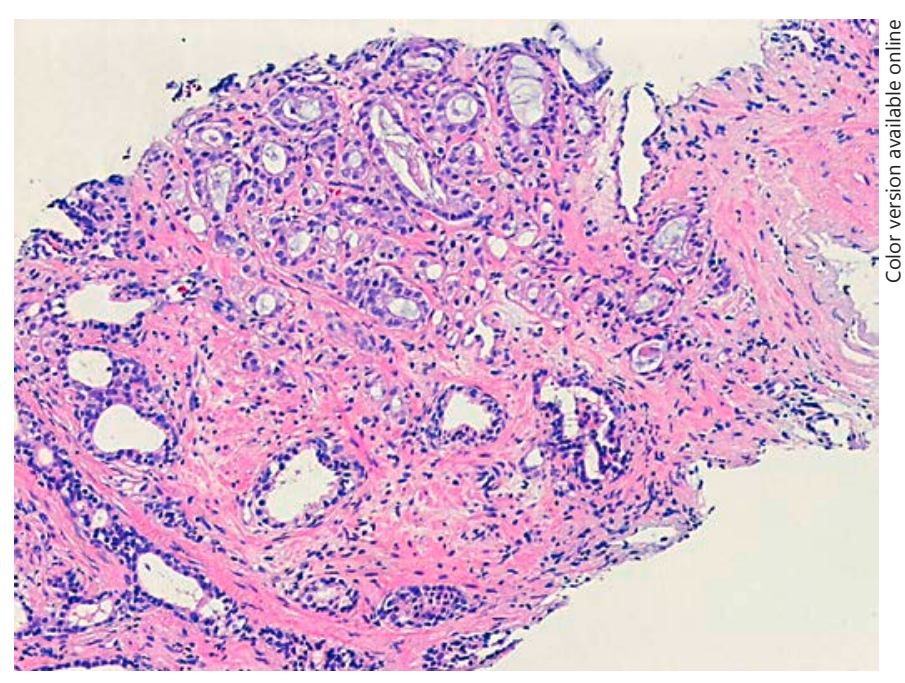

Fig. 2. Transrectal prostate biopsy findings that led to the diagnosis of adenocarcinoma Hematoxylin and eosin stain. $\times 100$. jaundice including intrahepatic ductal dilatation (Fig. 1). The serum prostate-specific antigen level was as high as $7,895 \mathrm{ng} / \mathrm{mL}$ (normal range: $0-4 \mathrm{ng} / \mathrm{mL}$ ). A prostate biopsy revealed adenocarcinoma (Fig. 2), and a liver biopsy revealed a canalicular type of cholestasis without evidence of liver metastasis (Fig. 3).

Despite 20 days of supportive care, the patient's SBL did not improve. After 3 days of $40 \mathrm{mg}$ prednisone therapy, sudden deterioration of the jaundice was observed. Although the corticosteroid therapy was discontinued, his SBL increased to $25.25 \mathrm{mg} / \mathrm{dL}$. Considering the jaundice to be a paraneoplastic manifestation of prostate cancer, antiandrogen treatments with $50 \mathrm{mg}$ bicalutamide and $3.6 \mathrm{mg}$ goserelin were started. Six days later, his jaundice improved dramatically, with his SBL decreasing to $7.22 \mathrm{mg} / \mathrm{dL}$. Three months after the hormone therapy, his serum prostate-specific antigen level decreased from 7,895 to $311 \mathrm{ng} / \mathrm{mL}$, and his bilirubin level was normalized without any adverse reaction (Fig. 4).

\section{Discussion}

Cholestatic manifestation of paraneoplastic syndrome in association with prostate cancer is rare. A few previous cases have been reported [1-9] and 7 cases showed improvement after hormone therapy (Table 1). From a therapeutic point of view, corticosteroids have been used to treat metastatic prostate cancer for decades [10]. In con- 
Fig. 4. Clinical course of the patient. ALT, alanine aminotransferase; PSA, prostatespecific antigen (in $\mathrm{mg} / \mathrm{mL}$ ).

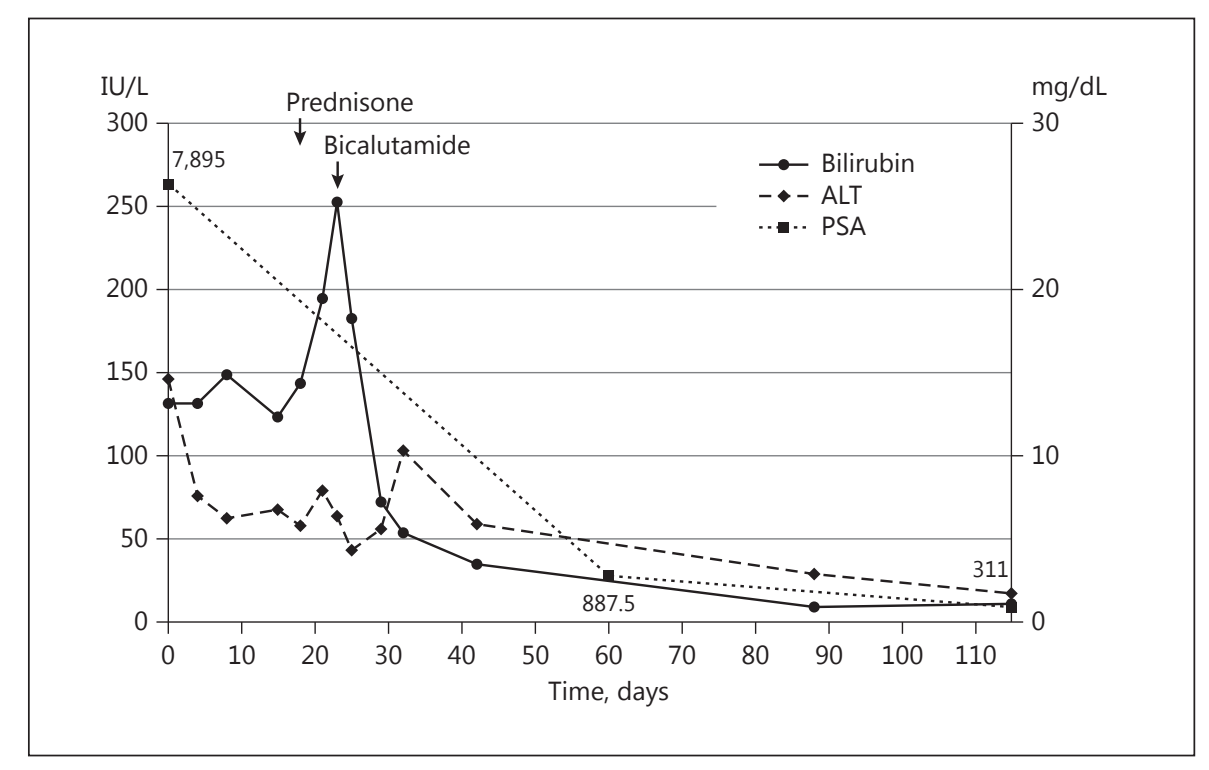

Table 1. Summary of cases of paraneoplastic cholestatic jaundice of prostate cancer

\begin{tabular}{|c|c|c|c|c|c|c|}
\hline Okano et al. [1] & 68 & $23.4 \mathrm{mg} / \mathrm{dL}$ & 15,018 & $\begin{array}{l}\text { Lymphocyte infiltration, } \\
\text { cholestasis }\end{array}$ & Bicalutamide & Improved \\
\hline Kuramoto et al. [2] & 75 & $17 \mathrm{mg} / \mathrm{dL}$ & 9,862 & ND & Bicalutamide, leuprolide & Improved \\
\hline Koruk et al. [3] & 77 & $10 \mathrm{mg} / \mathrm{dL}$ & 100 & Normal & Bicalutamide, goserelin & Improved \\
\hline Shah [5] & 64 & $302 \mathrm{mmol} / \mathrm{L}$ & 970 & ND & Goserelin, cyproterone & Unknown \\
\hline Nguyen et al. [6] & 51 & $19 \mathrm{mmol} / \mathrm{L}$ & 556 & ND & Bicalutamide, goserelin & Improved \\
\hline Karakolios et al. [7] & 72 & $18.1 \mathrm{mg} / \mathrm{dL}$ & 150 & ND & Flutamide, leuprolide & Improved \\
\hline Hinostroza-Yanahuaya & 70 & $29 \mathrm{mg} / \mathrm{dL}$ & 1,548 & ND & Conservative treatment & Expired \\
\hline et al. [8] & 84 & $3.96 \mathrm{mg} / \mathrm{dL}$ & ND & & & Expired \\
\hline Vieira et al. [9] & 78 & $12.3 \mathrm{mg} / \mathrm{dL}$ & $>1,000$ & ND & Bicalutamide, goserelin & Improved \\
\hline
\end{tabular}

PSA, prostate-specific antigen; ND, not done.

trast, we observed a deterioration of paraneoplastic jaundice in a patient with metastatic prostate cancer after a short course of prednisone, which improved after antiandrogen treatment.

Although no convincing pathogenesis was found, we suggest a hypothesis on the cause of the sudden deterioration. The use of corticosteroids in prostate cancer inhibits the secretion of adrenocorticotropic hormone in the pituitary gland, thereby reducing the synthesis of the adrenal androgen hormone, preventing cancer and improving the patient's symptoms [10] However, in the literature, corticosteroid use has been associated with the development of resistance to prostate cancer treatment $[10,11]$. The interaction of steroid hormones such as corticosteroids and androgens in prostate cancer has not been fully elucidated, especially in terms of growth receptors and androgen receptors (AR) [10]. In advanced stages of prostate cancer, the frequency of AR mutations 
is significantly increased [12]. Corticosteroids can activate the mutated AR to manifest an androgenic effect in metastatic prostate cancer, which in turn activates the growth receptor to induce cancer growth and stimulate genes that overlap with AR targets [11]. We suggest that administration of steroids may cause a sudden flare of paraneoplastic cholestasis, with elevation of bilirubin levels.

\section{Conclusion}

Paraneoplastic cholestasis should be considered when unexplained cholestasis occurs in cancer patients. In addition, paraneoplastic cholestasis due to prostate cancer can be improved with appropriate antiandrogen therapy and may be exacerbated by steroid use.

\section{Disclosure Statement}

No conflict of interest is reported.

\section{References}

1 Okano A, Ohana M, Kusumi F: Idiopathic cholestatic jaundice may be a paraneoplastic manifestation of underlying malignancy: a case of prostate cancer. Clin J Gastroenterol 2014;7:278-282.

2 Kuramoto T, Senzaki H, Koike H, et al: Cholestatic jaundice as a paraneoplastic manifestation of prostate cancer. Case Rep Urol 2013; 2013:303727.

-3 Koruk M, Butukberber M, Savas C, et al: Paraneoplastic cholestasis associated with prostate carcinoma. Turk J Gastroenterol 2004;15:5355.
4 Reddy AN, Grosberg SJ, Wapnick S: Intermittent cholestatic jaundice and nonmetastatic prostatic carcinoma. Arch Intern Med 1977; 137:1616-1618.

5 Shah SH: Paraneoplasic liver dysfunction in prostate cancer. J Pain Symptom Manage 2006;32:511-513.

-6 Nguyen V, Gurney H, van der Poorten D: Paraneoplastic hepatic dysfunction in metastatic prostate cancer: the role of cytokine dysregulation. J Clin Oncol 2011;29:e21-e23.

7 Karakolios A, Kasapis C, Kallinikidis T, et al: Cholestatic jaundice as a paraneoplastic manifestation of prostate adenocarcinoma. Clin Gastroenterol Hepatol 2003;1:480-483.

$>8$ Hinostroza-Yanahuaya J, Mon-Mon C, Ortega-Marcos O, et al: Stauffer syndrome and prostate carcinoma, two cases in chronic haemodialysis patients. Nefrologia 2013;33:749750 .
-9 Vieira AC, Alvarenga MJ, Santos JC, et al: Paraneoplastic jaundice and prostate cancer. BMJ Case Rep 2017;2017:bcr-2016-218001.

10 Porta C, Bracarda S, Danesi R: Corticosteroids and prostate cancer: friend or foe? Eur Urol 2015;67:680-682.

11 Chang CY, Walther PJ, McDonnell DP: Glucocorticoids manifest androgenic activity in a cell line derived from a metastatic prostate cancer. Cancer Res 2001;61:8712-8717.

12 Li Y, Sarkar FH: Role of BioResponse 3,3' -diindolylmethane in the treatment of human prostate cancer: clinical experience. Med Princ Pract 2016;25(suppl 2):11-17. 